Administrative Issues Journal: Connecting Education, Practice, and Research, Winter 2016, Vol. 6, No. 2: 116-133. doi:10.5929/2016.6.2.7

\title{
Cheating in Online Courses for Financial Aid Fraud in the U.S.
}

\author{
Robert S. Owen, Ph.D. \\ Texas A\&M University-Texarkana
}

\begin{abstract}
This manuscript reviews issues that differentiate traditional academic cheating from course misconduct that is motivated by a desire to defraud financial aid services in the U.S. Past research on college student cheating has assumed that cheaters are driven by an incentive to obtain undeserved grades in college in order to ultimately obtain a degree. However, researchers on academic dishonesty, professors, and college administrators might not realize that online class members can include virtual "straw" students who are puppets of a financial aid fraud ring leader. Cheating behaviors of straw students differ from cheating behaviors of actual, legitimate students. This has implications for those who attempt academic dishonesty research in online environments, and it has implications for course-level professors and university administrators who are in a "should have known" position with regard to discovery of a financial aid fraud ring.
\end{abstract}

Key words: online cheating, academic dishonesty, academic misconduct, financial aid fraud, Pell runner, straw student

n spring 2014, two sisters and a cousin were sentenced to serve U.S. federal prison terms and to pay over $\$ 417,000$ in restitution for running a student financial aid fraud ring during the years 2003 to 2011. During this time, the ring leaders used the identities of at least 20 people, logging themselves into online courses as these "straw students," probably submitting work for those virtual students that would resemble cheating to a professor who was paying attention. Their interest was not in gaining a college education; none of the three even had a high school diploma or GED (U.S. test to obtain certificate equivalent of high school diploma). Their interest through the eight years of this fraud was to obtain and pocket the excess balance or difference between the amount of financial aid awarded and the cost of tuition (U.S. Department of Education, 2014b, 2014d).

In another case, a ring leader agreed to repay over $\$ 581,000$ for money obtained through Stafford loans and Pell grants. She admitted to submitting 64 false applications to Rio Salado College for people who had no intention of becoming active students and to maintaining records of 136 potential "straw" students. She logged in to Rio Salado's online classes under the names of each of the straw students in order to generate the appearance of class participation by names on the class rolls - and it is difficult to imagine that a professor would not have noted an appearance of cheating when one person was 
submitting all of the assignments for so many students. Again, the interest of this fraudster was not to receive an education or a diploma for these straw students, but to pocket the difference between funds loaned or granted in the government programs and the amount of tuition and fees that the college kept (U.S. Department of Education, 2010).

Financial aid fraud has become an increasingly lucrative and problematic criminal activity in the U.S. Between 2005 and 2011, the U.S. Department of Education criminally convicted participants in 42 different fraud rings, seeking $\$ 7,521,840$ in restitution and fines (U.S. Department of Education, 2011). A risk analysis conducted by the U.S. Department of Education determined that potential student aid fraud ring activity had increased 82 percent from the 2009-10 academic year to 2012-13; the analysis identified over 85,000 recipients who might have participated in student fraud ring activity and received over $\$ 874$ million in Federal student financial aid, estimating that $\$ 187$ million was a "probable loss" due to fraud (U.S. Department of Education, 2013a). In just the six months between October 1, 2013 and March 31, 2014, the U.S. Department of Education closed 73 investigations involving fraud or corruption with more than $\$ 18.7$ million in settlements and other recoveries, including investigations of individuals, fraud rings, and school officials (U.S. Department of Education, 2014c).

An objective of the present manuscript is to sort out the differences between academic fraud, whereby a student cheats in order to obtain an academic credential, and the financial aid fraudster, whereby an individual student cheats or a fraud ring cheats for a group of straw students in order to maintain a superficial appearance of student participation to obtain financial aid funds. This assessment is done in part by assessing the environment of student financial aid fraud to help identify specific potential student cheating behaviors that are associated with financial aid fraud. The hope is to find factors that might suggest the presence of a potential for financial aid scams, primarily associated Title IV (U.S.) student aid funds, but also associated with other forms of federal and private student aid grants and loans. Without an understanding that these behaviors might be associated with a scam for financial gain, an individual professor could only observe student behaviors associated with financial aid fraud as bizarre-academically odd and inexplicable. A natural reaction would be to simply ignore these students and assign a failing grade. By merely assigning a failing grade, however, the professor becomes an essential component of the fraud process, enabling the fraud rings to continue without drawing attention.

In order to understand the differences between academic cheaters and financial aid fraud rings, we must first understand how financial aid fraud is committed, who it is that commits financial aid fraud, factors that enable financial aid fraud, and factors that can be used to assist in identifying when financial aid fraud is being committed. With this understanding, we can then move on to identify differences between a traditional academic cheater and a financial aid fraudster and financial aid fraud rings. This manuscript concludes with recommendations for minimizing financial aid fraud at the professor and administrative levels and with an appeal for considering the effects of financial aid fraud in scholarly studies of academic cheating. 


\section{How Financial aid Fraud Works}

When a professor teaching an online course initially notices a group of students exhibiting certain nonsensical patterns of participation and performance (from an academic perspective), and then the same group of students suddenly quits participating completely, the professor's reaction could be to simply assign a failing grade. What the professor fails to realize is that course failure might have been these students' intention from the start and that some of these "students" might not even exist in any form other than as bogus student names. Since many professors have been conditioned to ignore cheating and strange behaviors (e.g., Keith-Spiegel, Tabachnick, Whitley, \& Washburn, 1998), we can expect that they never get to the point of questioning why they have a continued problem of downright strange patterns of cheating and deadbeats in their classes. Given professors' conditioning to stay uninvolved in student cheating, it would never occur to them that they might be enabling the misdeeds of an organized crime ring.

Course cheating for financial aid fraud follows a general model (cf., U.S. Department of Education, 2011, 2013b, and other cited reports of this organization): a ringleader either recruits people willing to serve for a fee as "straw" students or steals the identity of people not likely to learn of the fraud until years later (e.g., someone who is incarcerated). For him/herself and the straw students, the ringleader completes college application processes that have low identity requirements such as online college applications and the U.S. Title IV financial aid forms (which do not require confirmation of identity). The scam ringleader is especially interested in targeting

- open-enrollment colleges;

- colleges with low tuition;

- colleges that focus on achieving headcount rather than a reputation for educational quality; and

- online programs that lack requirements for any physical presence.

The scammer's interest is not the attainment of college degrees for the straw students or him/herself, but the attainment of the cash difference between the amount of financial aid awarded and the fees of course enrollment. Colleges that are the most desirable targets, then, are those with low tuition in addition to open enrollment and online course offerings. Course cheating is therefore not done for the purpose of achieving a good course grade, but to maintain the status of a legitimate student for the purpose of obtaining financial aid refund amounts that exceed tuition and fee costs.

In order to identify forms of student cheating and other behaviors that might suggest the presence of a potential financial aid scam, we should first become familiar with who commits financial aid fraud, why they do it, and the environmental opportunities and individual incentives that exist to defraud the system. Once we have that background, we can then outline patterns of behaviors that financial aid fraudsters exhibit in contrast with patterns of behaviors that "traditional" academic cheaters exhibit.

OWEN / doi:10.5929/2016.6.2. 


\section{Who Commits Financial aid Fraud and Why}

Title IV and related financial aid fraud in the U.S. can be committed by school officials who assist in and gain from such fraud, by individual students, and by loosely organized financial aid fraud rings (cf., U.S. Department of Education, 2014c).

\section{Fraud by School Officials}

School officials sometimes engage in financial aid fraud in order to boost school enrollment numbers. A (former) financial aid director pled guilty to falsifying student financial aid applications in order to receive funds for which the students were not eligible, and the school agreed to an almost $\$ 687,000$ settlement (U.S. Attorney's Office, 2013). Students in these cases aren't necessarily interested in committing fraud for the sake of non-academic benefits, and it is possible in some cases that the students aren't even aware that a fraud has been committed; that is, the fraud could be committed by university officials without students' knowledge in order to boost school enrollment and revenues. If the fraud is committed by the school or school official, there is the possibility that the school stands to benefit from an increase in head count and an associated increase in revenues from the student aid and other sources of revenue that are based on student head counts. This is of interest to the present manuscript because colleges and university officials that are desperate for head counts could be contributing to the problem by actively recruiting from fraud rings or by being passive participants in fraud by knowingly ignoring warning signs that fraud rings could be operating within their institutions.

\section{Fraud by Individual Students}

In December 2014, a father pled guilty to submitting false tax return information in support of financial aid applications for scholarships from schools and for federal financial aid for two children (U.S. Department of Education, 2014e). For the sake of the present manuscript, this kind of fraud is perhaps as much aligned with academic misconduct as with financial aid fraud because the fraud was presumably committed for the (undeserved) benefit of students who had the intention of performing academically as active, legitimate students. That is, the student (or parent) was sincerely attempting to obtain an academic benefit, but at an unfairly reduced cost. Of interest in the present manuscript is differentiating between students who have an academic interest and fraud rings or individuals who commit the fraud for financial benefit with no intention of obtaining an academic benefit.

Fraud for academic benefits at lower cost. The two siblings in the case above, presumed to have an interest in attending college and obtaining a degree (albeit with undeserved financial assistance), are likely to behave in academically expected ways by taking exams, submitting homework assignments, participating in class activities, etc. If these students were to be caught in academic cheating, one would expect it to be in association with attempting to obtain a higher grade than deserved because this is associated with achieving an academic goal.

Fraud for financial benefits without academic motivation. Contrast these two students with the case of a student who enrolled in six different colleges in Ohio across five years in order to receive 
federal student aid benefits without an intention of obtaining a degree (U.S. Department of Education, 2014a). The student in this second case has a financial rather than academic goal: the student's interest is in maintaining the appearance of participation long enough to receive a financial aid refund disbursement, but the participation is not of a quality and length to achieve any academic goals. Unlike the students in the first case, academic cheating by the student in this second case would not be for academic benefit, but would be committed merely for sustaining the appearance of academic participation long enough to receive a financial aid check in mid-semester, thereby accomplishing a nonacademic goal of maintaining a financial stream.

\section{Fraud by Fraud Rings}

Fraud by a financial aid fraud ring is a variation on financial aid fraud committed by the individual student in the second case above. Fraud rings are "large, loosely affiliated groups of individuals who conspire to defraud Title IV programs through distance education programs" (U.S. Department of Education, 2011). Both the individual fraudster and the fraud ring are using financial aid in order to pocket the difference between the amount of financial aid and the costs of tuition and fees. The difference is that the individual is a real person who performs academically long enough to receive the financial aid check, and much of this performance probably requires some genuine work on the part of the student. The straw students associated with a theft ring, on the other hand, are more likely performing through a special form of cheating; the straw students are either people who willingly permit a ringleader to enroll them into courses, are victims of identity theft who do not realize that they are enrolled into courses, or could even be totally non-existent entities that are enrolled by fictitious name only. Fraud rings first became a problem for the Apollo Group (owner of University of Phoenix and other for-profit educational institutions) in 2008. Within about three years, the Apollo Group had uncovered about 750 fraud rings of an average size of 19 students (Fain, 2011).

When these phantom "straw" students quit performing in a course, the fraud ringleader can keep the difference between the straw student's tuition cost and the amount of financial aid that was awarded to the straw student. With several straw students, the fraud ringleader can amass a substantial sum of money without attracting notice. A professor might notice the unusual behavior of, say, 19 students exhibiting the same cheating patterns in an online course and then all ending participation in the same week of the semester. But without knowing that this is behavior potentially associated with financial aid fraud, the professor is likely to ignore the problem as merely an odd coincidence.

\section{Factors that Enable and Encourage Financial aid Fraud}

Several environmental factors have come together to enable or even encourage financial aid fraud. These include a national agenda for increasing college enrollments; the ease of obtaining Title IV financial assistance exceeding college costs; the ease of obtaining individual student loans from private lenders; the issuing of financial aid as cash, not as an expense reimbursement; the ease of creating straw students by means of identity theft; the lack of rigorous positive identity requirements for online application processes and courses; the ability to hide straw students because of the increasing 
prevalence of online course delivery; and incentives for colleges to ignore or participate in financial aid fraud precipitated by declining budgets and enrollments.

\section{A National Agenda for Increasing College Enrollments}

Organizations that have an influence on U.S. education policy have been pushing for higher numbers of high school graduates to attend college, including appeals by the current U.S. president, Barack Obama (e.g., Increasing College Opportunity for Low Income Students, 2014). The College Board, for example, would like to see $55 \%$ of young adults in the U.S. have at least a two year college degree by the year 2025, a desire driven by international data showing the U.S. as declining in rank among other nations with regard to the percentage of young adults with a college degree (Hughes, 2013). From an assessment of data in the Digest of Education Statistics (National Center for Education Statistics, n.d.), the Pew Research Center reported that, in 2012, 51\% of low income high school graduates were enrolled in college, up from $31 \%$ in 1975 , compared with an increase of $65 \%$ to $81 \%$ across the same period for high income high school grads, accompanied by an editorial implication that the U.S. needs to find ways to get more people from certain groups into college (DeSilver, 2014). A Brookings Institution analysis concludes that "the majority" of "low-income high-achievers" do not apply to selective colleges, behaving in a way that is typical of their income status rather than their academic achievement even though low income high achievers are found to persist in college like their high income counterparts (Hoxby \& Avery, 2013). Low-cost, non-selective colleges that might otherwise be the bottom choices of potential customers now find a market potential that includes students with an ability to pay tuition.

\section{Ease of Obtaining Title IV Financial Assistance that Exceeds College Costs}

Statistics and conclusions such as those above can currently be found in a push by President Obama for increases in grants and student loans to college students ("Higher Education,",n.d.). Between the school years 2005-06 and 2010-11, the average individual Pell Grant award increased from \$2,486 to \$4,115 and from 5,468,000 total recipients to 8,873,000 ("Pell Grant Historical Figures," n.d.). Between the first quarter of 2005 and the fourth quarter of 2012, the average individual student loan debt balance increased from $\$ 15,651$ to $\$ 24,803$, and from $23,300,000$ total borrowers to $38,800,000$ (Federal Reserve Bank of New York, 2013). It does indeed appear that the U.S. Federal government has been attempting to make it financially easier for people to attend college, but this also makes financial aid awards a more attractive target for fraudsters.

\section{Ease of Obtaining Individual Student Loans from Private Lenders}

Loans from private lenders such as banks are made at higher interest rates than those through Title IV programs, but they are easier to obtain, and fraud can be easier to hide. Private lending for a student loan is as easy as obtaining a loan to buy a car and does not require the Federal FAFSA application process. A legitimate student who qualifies for a Title IV loan would be expected to avoid a private loan due to the higher interest rate; however, interest rate is a non-issue to a fraudster who has no intention of making repayment. To the fraudster, student loan repayment is deferred for several years and therefore not subject to default for several years. Unlike the loan for, say, an automobile, identity theft 
victims do not quickly learn that their name was used to obtain a loan that paid cash to the thief for several years (Clark, 2008).

\section{Financial Aid Issued as Cash, Not as an Expense Reimbursement}

In the form of a Title IV Pell Grant, Stafford Loan, or Perkins Loan, the amount of Federal financial aid is determined on the basis of income, not on the exact costs of tuition, books, or room and board costs. The school receives the money, keeps the amount that it is owed for tuition and such, and disburses the remainder to the student. The student is permitted to spend that disbursement as s/he desires, whether it used to buy school supplies or on recreation time at the local pool hall (Federal Student Aid, n.d.; Kantrowitz, n.d.). In the form of a private bank loan, the student receives a check with no requirement to begin repayment until the student is no longer in school. As long as the student pays the school and remains a student, $s /$ he can continue to collect the full amount of the per-semester bank loan.

\section{Identity Theft for Creating Straw Students Is Easy}

Financial aid fraud rings don't necessarily need to use identity theft in order to create a pool of straw students. They can use anyone who, usually for financial compensation, is willing to permit their personal information to be used in the creation of a straw student. But identity theft is relatively easy and desirable because it does not require financial compensation to the straw student. All that is needed is a social security number, a birth date, and possibly other identifying information such as address and phone number (Frank, n.d.). PeopleinfoFind.com offers a money back guarantee to find someone's social security number; birthdates and other personal information of many people can be found on social websites such as Facebook, sometimes on government websites (e.g., the Texas sex offender registry displays birthdate in addition to photograph, weight, height, eye and hair color, even shoe size), or on websites devoted to aggregating detailed information from such sources (e.g., http://stevemorse.org/birthday/birthday2.html).

Fraud rings often steal the identities of real people to use as straw students are used to gain acceptance into a college, to-obtain a student loan, and toregister into classes. Unless the victim finds that his/her name was used to obtain a student loan, s/he might not find out about the fraud until a default is made on the student loan repayment, which does not occur until years later when the fraudster ceases to register the straw student (either by meeting requirements for graduation or by being unable to continue to transfer schools through too many course failures). Stolen identities used for straw students have belonged to people with disabilities and people who are incarcerated (U.S. Department of Education, 2012) - people who might have difficulty repairing issues of a stolen identity or who might never even become aware that their identities have been used. The ring leader in one case obtained over $\$ 300,000$ in financial aid funds by using the stolen identities of over 50 inmates, and who had another 45 stolen inmate identities that would have been used if he had not been caught (U.S. Department of Education, 2011).

OWEN / doi:10.5929/2016.6.2. 


\section{Online Application Processes and Online Courses Lack Rigorous Positive Identity Requirements}

Title IV financial aid fraud is most easily committed, especially when a ring of straw students are being used, in situations that minimize identity verification. Special targets, then, are online applications and online course programs; if both of these are present, then the student need not physically present $\mathrm{him} /$ herself for identity verification (U.S. Department of Education, 2011), and Title IV does not require verification of identity (U.S. Department of Education, 2011). In an extensive literature review of cheating and online courses, Campbell (2006) notes that online courses are problematic if positive identification is not required for taking exams. Lacking positive identity, it is easy for a fraud ringleader to gain college acceptance of straw students, and it is easy for a ringleader to submit exams and assignments for each member of a ring of straw students taking the same course.

\section{Increasing Prevalence of Online Course Delivery Makes It Easy to Hide Straw Students}

In her extensive literature review of cheating and online courses, Campbell (2006) drew two major conclusions: 1) cheating is widespread, and 2) cheating is easier and more likely to happen in online courses. While a lone financial aid scammer could attend a face-to-face class and present minimal work until the financial aid disbursement check is sent, the requirement to be physically present in class makes it impossible for a single ringleader to run straw students through the class. However, several straw students can easily be given the appearance of participation with a minimal time investment by a single ringleader. A good grade need not be achieved for maintenance of participation evidence; the ringleader need only quickly submit random answers to multiple choice exams and failing, but participatory, written assignment submissions.

\section{Declining Budgets and Enrollments Create Incentives for Colleges to Ignore or Participate in Financial Aid Fraud}

Some colleges and universities in the U.S. potentially have incentives to turn a blind eye to passively profiting from Title IV financial fraud. Colleges and universities in the U.S. have recently been experiencing declining revenues tied to declining enrollments coupled with declining non-tuition revenues. Total enrollment across all Title IV degree granting institutions declined by $1.3 \%$ in Fall 2014, 1.5\% Fall 2013. and 1.8\% Fall 2012 (National Student Clearinghouse Research Center, 2014). U.S. states have trimmed financial support of public universities by an average of $40 \%$ between 1980 and 2011, with state support predicted to reach zero by 2059 at that rate (Mortenson, 2012). The university must give to the student the difference between its tuition and fees and the amount of aid that the student received. The fake student is committing fraud in order to receive that difference, but the institution stands to gain by keeping not only the tuition and fees, but also the semester-start headcount that is used in appealing for outside support.

Vatterott College, for example, received financial aid disbursements of almost $\$ 345,000$ for students who were ineligible. The campus co-director, the director of enrollment, and the supervisor for admissions representatives provided false GEDs (U.S. high school equivalency diplomas) and falsified financial aid forms for students who had neither a high school diploma nor GED (U.S. Department of

OWEN / doi:10.5929/2016.6.2.

Page 123 
Education, 2009). In a test of 15 for-profit colleges by the General Accounting Office, four undercover applicants were encouraged to falsify information in order to qualify for financial aid (GAO Testimony, 2010).

\section{Red Flags of Financial Aid Fraud}

The occurrence of student financial aid fraud might not be so difficult to ignore in the situation of commuter campuses with face-to-face classes. One common anecdotal joke is that professors can tell when the student aid checks have been disbursed: the parking lots are half empty the next day, and students quit submitting assignments with no concern about failing the course (e.g., Cheston, 2013; Marshall-Genzer, 2011; Ruth, 2014). But with completely online applications, online registrations, and online classes being pursued by colleges, such intuitively obvious and physically visible signs are missing. There are at least three places within a college and three points in a student's relationship with a college at which potential student aid fraud could be flagged:

- the financial aid office, when processing a financial aid application;

- the registrar's office as students drop courses, register for courses, repeat courses;

- and by individual professors who are aware of and track student behaviors as they progress through an individual course.

\section{Application Process}

Red flags that can be detected in association with a financial aid application include those associated with individuals and those associated with fraud rings. Students and their parents can alter and photocopy supporting documents such as tax returns, so excessive round numbers, smudges, etc. should probably receive extra scrutiny (cf., "FAA Guide to Detecting Fraud," n.d.). Individual transfer students who have attended several other colleges and have large student loan balances without completing a degree suggest a potential for fraud (cf., Baime \& Mullin, 2012). The possible presence of a fraud ring could be flagged by the observation of multiple uses of the same mailing address, bank account, computer, or emergency contact (cf., Baime \& Mullin, 2012).

\section{Class Registration, Performance Intervention, and Drop Process}

Red flags of financial aid fraud that could be detected among accepted students include individual students who quit class participation (in class or online) soon after financial aid refund or disbursement checks are mailed, students who continue to fail and repeat the same courses, and/or students who have amassed large financial aid refunds or disbursements. Red flags of the presence of a financial aid fraud ring include a rapid increase in the number of students in certain courses. (cf., Baime \& Mullin, 2012). 


\section{Learning Process, Course Performance}

To understand the reasons for these behaviors at the institutional level, and to understand the reasons for the behaviors that individual professors might notice in their face-to-face and online classrooms (presented later in this manuscript, following analysis), we must assess differences in the opportunities of and the motivations of academic cheaters and financial aid fraudsters. In order to understand the process of cheating for financial gain, we have to differentiate between an old-fashioned academic cheat and an academic financial aid scammer.

\section{Cheating for Academic Benefit vs. Cheating for Financial Benefit}

A general definition of cheating that might make a useful starting point is adapted from Yan and Randell (2009) in their studies of cheating in online games: Any behavior that a player uses to gain an advantage in achieving some objective that $s /$ he is not supposed to have achieved. This definition is focused and deliberately kept simple in sidestepping issues of altruistic behaviors and motivations, peer pressure, etc. (An exhaustive discussion of such variables and confounds can be found in Green, 2004.)

\section{Objectives of the Academic Cheat}

From this definition, we can speculate that the objectives of the academic cheat are to

- achieve a particular grade for less work than is legitimately required

- in order to successfully complete a course or a degree program

- with an ultimate goal of getting a good job or gaining admission into graduate school after graduation.

Articles on college student cheating often discuss academic cheating in association with "academic misconduct" or "academic dishonesty" (e.g., McCabe \& Trevino, 1993; Nonis \& Owens Swift, 1998; Stone, Kisamore, Jawahar, \& Bolin, 2014). Conclusions about college cheating and advice given to deter college cheating presume that cheaters are seeking an academic benefit that they know to be undeserved and morally wrong. For example, Hutton's (2006) synthesis, "Understanding Student Cheating and What Educators Can Do About It," is possibly a typical traditional "old school" perspective in drawing conclusions that students cheat for academic or social benefits that can be "substantially mitigated by promoting academic integrity as the social norm" (p. 171). Hutton recommends that freshmen orientations discuss academic policies, ethics, and sanctions, and that these be communicated with faculty as well. These recommendations are consistent with longstanding beliefs and empirical research supporting these beliefs that honor codes influence cheating behaviors of students (e.g., McCabe \& Trevino, 1993).

OWEN / doi:10.5929/2016.6.2. 


\section{Objectives of the Academic Financial aid Scammer}

From the above definition of cheating, we can speculate that the objectives of the academic financial aid scammer are to

- maintain the appearance of academic performance

- long enough to receive a financial benefit.

What the financial scammer wants is to stay in a course long enough for the school to send the financial aid disbursement check - the difference between the amount of financial aid awarded and the cost of tuition and related fees. When the scammer is a fraud ringleader, simultaneously using multiple identities of real or fictitious people, the financial net can be for tens or hundreds of thousands of dollars. For a financial scammer, the successful completion of a course or a degree is not the objective; only the receipt of a financial aid check is important.

Note the important difference between the objectives of the academic cheat and the financial aid scammer: one wants the school to award an academic credential (course grade, diploma); the other wants the school to send a disbursement check. The academic cheat wants to invest the minimal amount of effort required to achieve a desired academic credential; the financial aid scammer wants to invest the minimal amount of effort required to receive a disbursement check from the school. In the case of a financial aid fraud ring, the ring leader is cheating for the straw students so that they give the appearance of class participation, something that can probably be done only in an online course.

\section{Academic Cheats vs. Financial aid Straw Students}

The kind of cheating that is required to maintain a good course grade is different from the kind of cheating that is required merely to maintain a brief appearance of being a performing student. In order to maintain the appearance that straw students are active participants in a course, the ring leader must continue to submit assignments that appear to be credit worthy, even if that credit is the award of a failing grade. A traditional academic cheat is motivated to achieve a mark that is higher than was supposed to have been achieved for the amount of effort expended; the financial aid scammer merely needs a grade-even a failing grade will do-that gives the appearance of participation.

Online multiple choice exams. To achieve the goal of a better grade on an online multiple choice exam, the traditional academic cheat will make the effort to obtain a textbook, a publisher's testbank, or an archive of a professor's prior exams, or to copy another student's exam in an unproctored online environment. The traditional deterrence to this is to individually generate on-the-fly exams of randomly chosen questions from a large question pool (e.g., Rowe, 2004) and/or proctor online exams with a webcam.

But the financial aid scammer or the ringleader for a group of financial aid straw students can submit random answers on a multiple choice exam and the failing grade that results provides the appearance of

OWEN / doi:10.5929/2016.6.2.

Page 126 
participation. The financial aid cheat actually has a dis-incentive for achieving a passing grade: Title IV financial aid can be paid for as long as a student has never passed a course, but it will pay for only one retake of a course that has been passed (U.S. Department of Education, 2013b).

Online written plagiarism. In addition to differences in outcomes on multiple-choice exams, individual academic cheats and a ring of financial aid straw students will show different performances on cases of written plagiarism. Motivated to get higher grades, academic cheats will attempt to copy from the work of better students and will personally re-tailor an essay or report using natural language skills. Since many financial aid fraud ringleaders are not academically qualified to attend college in the first place, the original works that they write will probably not be especially good, nor will they need to be if the objective is merely to give the appearance of participation. But the derived work that is plagiarized and submitted on behalf of the straw students will likely not be re-tailored using natural language skills because of the amount of effort involved.

The self-plagiarized work that a financial aid fraud ringleader submits on behalf of the straw students is more likely to have been automatically generated from an article spinner. An article spinner is a machine application that re-generates sentences and paragraphs through such means as substituting synonyms.

Run through the free online article spinner at spinbot.com, the above paragraph is rewritten as

The appropriated toward oneself work that a monetary support extortion instigator submits for the benefit of the straw understudies is more inclined to have been made from a text rewriter. A text rewriter is a machine application that re-produces sentences and passages through such means as substituting equivalent words.

When that word-spun paragraph is recycled through the same article spinner, it comes out as:

The appropriated toward oneself work that a financial bolster blackmail instigator submits for the profit of the straw understudies is more slanted to have been produced using a content rewriter. A content rewriter is a machine application that re-produces sentences and sections through such means as substituting identical words.

The professor of an online course might believe that the second two paragraphs are a bit bizarre, but whatever the grade assigned, these might be accepted as reasonable attempts at course participation. Some students might not belong in college, but a professor at an open enrollment school must be as accepting as possible. If the professor is able to recognize that these three student submissions are similar enough in paragraph structure to constitute plagiarism, the worst that is likely to happen is a failing grade on the assignment for two or for all three of the students. But the ringleader won't care because a grade is proof that all three course enrollees are participating students. A financial aid disbursement will be sent to all three. And after the financial aid disbursement checks are mailed and cashed, all three students will quit participating in the course, all three will fail the course, and all three will be eligible to repeat the course with financial aid benefits intact.

OWEN / doi:10.5929/2016.6.2.

Page 127 


\section{Conclusion}

Financial aid fraud, especially when mass-produced by the ringleaders of fraud rings, has become an increasingly prevalent and costly problem in the U.S. Fraud rings are enabled in part by the increasing use of online college admissions with lax identity requirements and the increasing use of online courses and programs with lax identity requirements. Once a ringleader and group of straw students are admitted into an online program, the fraud ringleader must rely on cheating, which can be easy in online courses at schools with lax identification requirements.

The behaviors of cheaters committing financial aid fraud are different from behaviors associated with committing academic fraud, especially in the case of financial aid fraud rings (see Table 1). The differences in behaviors stem from the differences in motivation for cheating: the academic fraud uses cheating as a way to obtain undeservedly higher academic marks, whereas the financial aid scammer uses cheating as a way to prolong the appearance of classroom participation. The academic fraud most likely holds the longer term goal of obtaining good grades that will lead not only to passing a course, but to a degree or credential that will lead to a good job and good career far into the future. The financial aid scammer merely wants to maintain the appearance of course participation long enough to receive a financial aid refund disbursement. The academic cheat is likely to complete a course and a program of study in good standing; if courses are dropped or retaken, this is associated with an attempt to maintain higher grades. The financial aid scammer is likely to perform poorly in a course and to stop participating at some point in the course rather than drop a course. The implications of this are not just associated with the financial well-being of lenders, grantors, and universities, but, importantly, affect the kinds of conclusions that are drawn from interpretation of results in research on academic cheating (conclusions summarized in Table 1).

OWEN / doi:10.5929/2016.6.2. 
Table 1

Cheating to Achieve Academic Fraud vs. Cheating to Achieve Financial Fraud

\begin{tabular}{|c|c|c|c|c|}
\hline & \multicolumn{2}{|c|}{ ACADEMIC FRAUD } & \multicolumn{2}{|r|}{ FINANCIAL AID FRAUD } \\
\hline & $\begin{array}{l}\text { Traditional } \\
\text { Academic } \\
\text { Cheaters }\end{array}$ & $\begin{array}{l}\text { Financial Aid } \\
\text { Abusers }\end{array}$ & Financial Aid Scammers & Financial Aid Fraud Rings \\
\hline WHO & $\begin{array}{l}\text { Individual } \\
\text { students or } \\
\text { cheating ring }\end{array}$ & $\begin{array}{l}\text { Individual } \\
\text { students or } \\
\text { parents }\end{array}$ & Individual students & $\begin{array}{l}\text {-Ring leaders } \\
\text {-Straw students }\end{array}$ \\
\hline MOTIVES & $\begin{array}{l}\text { Obtain higher } \\
\text { grade than } \\
\text { deserved for } \\
\text { or effort } \\
\text { invested }\end{array}$ & $\begin{array}{l}\text { Lower cost of } \\
\text { academic access }\end{array}$ & $\begin{array}{l}\text { Obtain financial benefit } \\
\text { for self without regard to } \\
\text { educational outcome }\end{array}$ & $\begin{array}{l}\text {-Ring leader: obtain financial benefit for self } \\
\text { across many students without regard to } \\
\text { educational outcome } \\
\text {-Straw student: flat fee payment from ring } \\
\text { leader for permitting use of personal } \\
\text { information or in the case of identity theft, } \\
\text { no benefit at all }\end{array}$ \\
\hline $\begin{array}{l}\text { IDEAL } \\
\text { TARGET } \\
\text { SCHOOLS }\end{array}$ & Any & $\begin{array}{l}\text { Highest ranked } \\
\text { school for which } \\
\text { this student can } \\
\text { qualify }\end{array}$ & $\begin{array}{l}\text {-Low, easy entrance } \\
\text { requirements } \\
\text {-Low tuition and fees }\end{array}$ & $\begin{array}{l}\text {-Online application, online program } \\
\text {-No proof of identity required in application } \\
\text { or for course or program completion } \\
\text {-Low entrance requirements } \\
\text {-Low tuition and fees }\end{array}$ \\
\hline METHODS & $\begin{array}{l}\text {-Plagiarize } \\
\text { work of other } \\
\text { students or } \\
\text { sources } \\
\text {-Obtain } \\
\text { unauthorized } \\
\text { course } \\
\text { materials }\end{array}$ & $\begin{array}{l}\text { Misreport } \\
\text { qualifications for } \\
\text { aid (e.g., income } \\
\text { in aid } \\
\text { applications) }\end{array}$ & $\begin{array}{l}\text {-Apply to schools with } \\
\text { lower costs than financial } \\
\text { aid benefits }\end{array}$ & $\begin{array}{l}\text {-Apply ringleaders and straw students to } \\
\text { schools with lower costs than financial aid } \\
\text { benefits }\end{array}$ \\
\hline SIGNALS & $\begin{array}{l}\text {-Evidence of } \\
\text { plagiarized } \\
\text { work and/or } \\
\text { unauthorized } \\
\text { course } \\
\text { materials, } \\
\text { AND } \\
\text {-An attempt to } \\
\text { complete a } \\
\text { course of } \\
\text { study with } \\
\text { highest marks } \\
\text { for least } \\
\text { amount of } \\
\text { effort }\end{array}$ & $\begin{array}{l}\text {-Sincere effort as } \\
\text { a student } \\
\text { AND } \\
\text {-Evidence that } \\
\text { qualifications } \\
\text { were mis- } \\
\text { represented }\end{array}$ & $\begin{array}{l}\text {-Evidence of traditional } \\
\text { academic cheating early } \\
\text { in course } \\
\text {-Weak effort; e.g., } \\
\text { minimal attendance or } \\
\text { minimal online login } \\
\text { meant to give an } \\
\text { appearance of activity } \\
\text {-Minimal concern for } \\
\text { grade; even a failing } \\
\text { grade is acceptable } \\
\text {-Less or total absence of } \\
\text { participation after } \\
\text { financial aid checks are } \\
\text { mailed }\end{array}$ & $\begin{array}{l}\text {-Almost exclusively online courses } \\
\text {-Evidence of traditional academic cheating } \\
\text { early in course } \\
\text {-Weak effort; e.g., minimal attendance or } \\
\text { minimal online login meant to give an } \\
\text { appearance of activity } \\
\text {-Minimal concern for grade; even a failing } \\
\text { grade is acceptable } \\
\text {-Same student is always involved in } \\
\text { plagiarism issues (the ringleader; cheating is } \\
\text { otherwise rotated among the straw students } \\
\text { who never respond to accusations or } \\
\text { complain when accused of cheating) } \\
\text {-Timing of online logins are sequential among } \\
\text { same group of students } \\
\text {-Less or total absence of participation after } \\
\text { financial checks are mailed }\end{array}$ \\
\hline
\end{tabular}

OWEN / doi:10.5929/2016.6.2.

Page 129 
References

Baime, D. S., \& Mullin, C. M. (2012, April). Preventing abuse in federal student aid: Community college practices. American Association of Community Colleges. Washington, DC: U.S. Department of Education.

Campbell, H. E. (2006). Cheating, public administration, education, and online courses: An essay and call to arms. Journal of Public Affairs, 12(1). 33-47.

Cheston, D. (2013, February), Pell running. The John William Pope Center for Higher Educational Policy. Retrieved from http://www.popecenter.org/commentaries/article.html?id=2811

Clark, K. (2008, June 25). Five charged with $\$ 690,000$ in student loan fraud. U.S. News and World Report. Retrieved from http://www.usnews.com/education/articles/2008/06/25/fivecharged-with690000-in-student-loan-fraud

DeSilver, D. (2014, January 15). College enrollment among low-income students still trails richer groups. Factank: News in the Numbers. Pew Research Center. Retrieved from http://www.pewresearch.org/fact-tank/2014/01/15/collegeenrollment-among-low-incomestudents-still-trails-richer-groups/

Fain, P. (2011, October 11). Hitting hard on fraud. Inside Higher Ed. Retrieved from https://www.insidehighered.com/news/2011/10/11/community colleges push back on prop osed regulations targeting fraud rings

Federal Reserve Bank of New York (2013). Student loan debt by age group. Retrieved from http://www.newyorkfed.org/studentloandebt/

Federal Student Aid (n.d.). Your college or career school-not the U.S. Department of Education-will distribute your financial aid. Retrieved from https://studentaid.ed.gov/fafsa/next-steps/receiveaid

FAA guide to detecting fraud on financial aid applications. (n.d.). Retrieved from Finaid!.org: http://www.finaid.org/educators/fraud.phtml

Frank, M. (n.d.). Frequently Asked Questions. IdentityTheft.org. Retrieved from IdentityThef.org: http://www.identitytheft.org/faq.htm

GAO Testimony (2010, November 30). For profit colleges: Undercover testing finds colleges encouraged fraud and engaged in deceptive and questionable marketing practices. Testimony before the Committee on Health, Education, Labor, and Pensions, U.S. Senate, by Gregory Kutz, Managing Director Forensics Audits and Special Investigations. Reissue. Retrieved from http://www .gao.gov/products/GAO-10-948T

Green, S. P. (2004). Cheating. Law and Philosophy, 23. 137-185.

"Higher Education" (n.d.), whitehouse.gov. Retrieved from http://www.whitehouse.gov/issues Leducation/higher-education\#college-affordability

OWEN / doi:10.5929/2016.6.2.

Page 130 
Hughes, K. (2013). The college completion agenda 2012 progress report. Retrieved from The College Board Advocacy \& Policy Center http://media.collegeboard.com/digitalServices/pdf/advocacy Lcca/12b-6368 CCAProgressReport WR.pdf

Hutton, P. A. (2006). Understanding student cheating and what educators can do about it. College Teaching, 54(1), 171-176.

Huxby, C., \& Avery, C. (2013, spring). The missing "one-offs": The hidden supply of high-achieving low income students. Brookings Papers on Economic Activity. Retrieved from https://www.brookings .edu/bpea-articles/the-missing-one-offs-the-hidden-supply-of-high-achieving-low-incomestudents/

Increasing college opportunity for low-income students: Promising models and a call to action. (2014). [Washington, D.C.] : Executive Office of the President, The White House, 2014.

Kantrowitz, M. (n.d.), "When do I receive the Stafford Loan funds?" Edvisors. Retrieved from http://www.staffordloan.com/stafford-loan-info/faq/when-do-i-receive-stafford-loan-funds.php

Keith-Spiegel, P., Tabachnick, B. G., Whitley Jr., B. E., \& Washburn, J. (1998). Why professors ignore cheating: Opinions of a national sample of psychology instructors. Ethics \& Behavior, 8(3), 215227.

Marshall-Genzer, N. (31 May 2011), Some lawmakers target Pell Grants for cuts. MarketPlace Live. Retrieved from http://www.marketplace.org/topics/life/some-lawmakers-targett-pellgrants$\underline{\text { cuts }}$

McCabe, D. L., \& Trevino, L. K. (1993). Academic dishonesty: Honor codes and other contextual influences. Journal of Higher Education, 64(5), 522-538.

Mortenson, T. G. (Winter 2012). State funding: A race to the bottom. ACE: American Council on Education. Retrieved from http://www.acenet.edu/the-presidency/columns-andfeatures/Pages/state-funding-a-race-to-the-bottom.aspx

National Center for Education Statistics (n.d.), Digest of Education Statistics, U.S. Institute of Educational Sciences, U.S. Department of Education. Retrieved from http://nces.ed .gov/programs/digest/2013menu tables.asp

National Student Clearinghouse Research Center (2014). REPORT: Current Term Enrollment Report - Fall 2014. Retrieved from http://nscresearchcenter.org/currenttermenrollmentestimate-fall2014/

Nonis, S., \& Owens Swift, C. (1998). Managing academic misconduct in the classroom: A discriminant analysis of subject and situational differences between cheaters and non-cheaters." Proceedings of the 1998 Academy of Marketing Science (AMS) Annual Conference, 56-61. Springer International Publishing, 2015.

Pell grant historical figures. (n.d.). Retrieved from Finaid!.org: http://www.finaid.org/educators Lpellgrant.phtml

OWEN / doi:10.5929/2016.6.2.

Page 131 
Rowe, N. C. (2004). Cheating in online student assessment: Beyond plagiarism. Online Journal of Distance Learning Administration, 7(2). Retrieved from http://www.westga.edu 〜 distance/ojdla/summer72/rowe72.html

Ruth, D. (2014, February). Pell grant abusers: Education's biggest cheaters. New Orleans Magazine. Retrieved from http://www.myneworleans.com/Pell-Grant-Abusers/

Stone, T. H., Kisamore, J. L., Jawahar, I. M., \& Holden Bolin, J. (2014). Making our measures match perceptions: Do severity and type matter when assessing academic misconduct offenses? Journal of Academic Ethics, 12, 251-270. DOI: 10.1007/s10805-014-9216-0.

U.S. Attorney's office (15 April 2013). San Diego college pays $\$ 700,000$ and former financial aid director pleads guilty to resolve allegations of financial aid fraud. Federal Bureau of Investigation. Retrieved from https://archives.fbi.gov/archives/sandiego/press-releases/2013/san-diegocollege-pays-700-000-and-former-financial-aid-director-pleads-guilty-to-resolve-allegations-offinancial-aid-fraud

U.S. Department of Education (2009), Former Vatterott director pleads guilty to financial aid fraud. Investigative Reports, December 11, 2009. Retrieved from http://www2.ed .gov/about/offices/list/oig/invtreports/mo122009.html

U.S. Department of Education (2010), "Ringleader of $\$ 500,000$ financial aid fraud scheme sentenced to prison; 55 of 64 defendants have been sentenced to date." Investigative Reports, May 11, 2010. Retrieved from http://www2.ed.gov/about/offices/list/oig/invtreports/az052010.html

U.S. Department of Education (2011), Investigative Program Advisory Report: Distance Education Fraud Rings. U.S. Department of Education Office of Inspector General, Control No. L42L0001,September 26, 2011. Washington, DC: U.S. Department of Education. Retrieved from http://www2.ed.gov/about/offices/list/oig/invtreports/14210001.pdf

U.S. Department of Education (2012), "Indictments handed down in 7 separate student loan fraud schemes." Press release, U.S. Department of Education Office of Inspector General, September 18, 2012. Retrieved from https://www2.ed.gov/about/offices/list/oig/invtreports/ca092012.pdf

U.S. Department of Education (2013a), "Final management report." U.S. Department of Education Office of Inspector General, Control No. ED-OIG/X18M0001, January 17, 2013. Retrieved from https://www2.ed.gov/about/offices/list/oig/auditreports/fy2013/x18m0001.pdf

U.S. Department of Education (2013b), "Withdrawals and the return of Title IV funds", Federal Student Aid Handbook: Volume 5, Chapter 1. Retrieved from http://ifap.ed .gov/fsahandbook/attachments/1314FSAHbkVol5MASTER.pdf

U.S. Department of Education (2014a), "Cleveland man charged with fraudulently receiving $\$ 55,000$ in student financial aid." Investigation Report, April 9, 2014. Retrieved from http://www2.ed.gov/about/offices/list/oig/invtreports/oh042014.html 
U.S. Department of Education (2014b), "Georgia woman sentenced for student loan fraud scheme". Investigation Report, April 15, 2014. Retrieved from http://www2.ed .gov/about/offices/list/oig/invtreports/wi042014.html

U.S. Department of Education (2014c), Semiannual Report to Congress, No. 68, October 12013 - March 31, 2014. May, 2014. Washington, DC: U.S. Department of Education. Retrieved from http://www2.ed.gov/about/offices/list/oig/semiann/sar68.pdf

U.S. Department of Education (2014d), "Cousins sentenced for role in student loan fraud scheme," Investigation Report, July 09, 2014. Retrieved from http://www2.ed .gov/about/offices/list/oig/invtreports/wi072014.html

U.S. Department of Education (2014e), "Chelsea man pleads guilty to student financial aid fraud." Investigation Report, December 10, 2014. Retrieved from http://www2.ed .gov/about/offices/list/oig/invtreports/ma122014.html

Yan, J., \& Randell, B., (2009). An investigation of cheating in online games. IEEE Security \& Privacy, 7(3), 37-44.

\section{About the Author}

Robert S. Owen (robert.owen@tamut.edu) is an Associate Professor of Marketing in the College of Business, Texas A\&M University-Texarkana. He is a Registered Certified Electronics Technician with published research and interests that include human information overload, physical measurement and instrumentation, automatic tutoring, and cyber warfare. 